\title{
Arc GIS Based Interpretation of Surface Sediment Heavy Metals Near Coastal Area of District Badin, Sindh, Pakistan
}

\author{
Mohammad Amin Qureshi, ${ }^{1, ~}$, Ghulam Murtaza Mastoi ${ }^{1}$, Mushtaque Ahmed Baloch ${ }^{1}$, \\ Muhammad Ali Bhatti ${ }^{1}$, Sarfaraz Ali Mallah' ${ }^{2}$, Muhammad Waseem Junejo ${ }^{1}$, \\ Rashid Ali Malukhani ${ }^{1}$, Imran Ali Abbasi ${ }^{1}$
}

${ }^{1}$ Centre for Environmental Sciences, University of Sindh, Jamshoro, Sindh, Pakistan

${ }^{2}$ M. A. Kazi Institute of Chemistry University of Sindh Jamshoro, Sindh, Pakistan

\section{Email address:}

m-ameen-q@hotmail.com (M. A. Qureshi)

\section{To cite this article:}

Mohammad Amin Qureshi, Ghulam Murtaza Mastoi, Mushtaque Ahmed Baloch, Muhammad Ali Bhatti, Sarfaraz Ali Mallah ,Muhammad Waseem Junejo, Rashid Ali Malukhani, Imran Ali Abbasi. Arc GIS Based Interpretation of Surface Sediment Heavy Metals Near Coastal Area of District Badin, Sindh, Pakistan. American Journal of Environmental Protection. Vol. 4, No. 3, 2015, pp. 110-119.

doi: 10.11648/j.ajep.20150403.11

\begin{abstract}
The present study investigates heavy metal contamination of sediments of the surface drains, lakes and lagoons of coastal district Badin. The accumulation of industrial, municipal waste water, pumped saline water and agricultural runoff through left bank outfall drain (LBOD) and other linking drains in the coastal lines of Badin, Sindh, Pakistan, have disturbed the environmental ecology of the area. The heavy metal characteristics of sediments were analyzed, i.e. ionic and molecular species of $\mathrm{Hg}, \mathrm{Ni}, \mathrm{Fe}, \mathrm{Cd}, \mathrm{Pb}, \mathrm{Cr}, \mathrm{Co}, \mathrm{Cu}, \mathrm{Mn}$, and $\mathrm{Zn}$. Arc GIS application was used for mapping of the studied area. The obtained results were represented by GIS based maps, with graduated colored circles. A total of 31 sediment samples were taken from drains, lakes and lagoons of coastal areas. The average results, analyzed for heavy metals, were found as $\mathrm{Hg}(\mathrm{mg} / \mathrm{kg})$ $0.2032 \pm 0.173$, Ni $(\mathrm{mg} / \mathrm{kg}) 1.455 \pm 1.449, \mathrm{Cd}$ (Not Detected), $\mathrm{Zn}(\mathrm{mg} / \mathrm{kg}) 2.789 \pm 0.865, \mathrm{Cu}(\mathrm{mg} / \mathrm{kg}) 0.3050 \pm 0.3355$, $\mathrm{Fe}(\mathrm{mg} / \mathrm{kg}) 71.175 \pm 1.610, \mathrm{Mn}(\mathrm{mg} / \mathrm{kg}) 7.375 \pm 1.848$, Co $(\mathrm{mg} / \mathrm{kg}) \quad 0.0548 \pm 0.0634, \mathrm{~Pb}(\mathrm{mg} / \mathrm{kg}) 0.216 \pm .114, \mathrm{Cr}(\mathrm{mg} / \mathrm{kg}) 0.7054$ \pm 0.6949 . The obtained results indicated that pollution of heavy metal concentration in surface sediments of lakes, lagoons, and drains near coastal lines of Badin Sindh, posed a serious question. The main contaminating sources in the area are LBOD and other link drains, carrier of industrial effluents of different districts. Poor infrastructure of LBOD facilitates backward flow of contaminated sea tidal water towards coastal saline lakes, also adds in sediment pollution.
\end{abstract}

Keywords: Heavy Metals, Sediments, Lakes, Lagoons, Badin Coastal Area, LBOD (Left Bank Outfall Drain), Kadhan Pateji Outfall Drain (KPOD), Dhoro Puran Outfall Drain (DPOD),

GIS(Geographic Information System)

\section{Introduction}

Sediments consist of the loose sand, clay, silt, soil particles that settle at the bottom of a body of water. Soil particles transported by water are often deposited in rivers, streams, lakes, and wetlands. Water and wind brings these particles to rivers, lakes and other water bodies. They are repositories for a wide range of chemical and biological agents[1]. The heavy metal pollution of aquatic ecosystems has been a potential global problem. Heavy metals may enter into aquatic ecosystems from anthropogenic sources, such as industrial and sewage wastewater, fossil fuel combustion and atmospheric deposition [2].It is known that trace amounts of heavy metals are always present in fresh waters from weathering of rocks resulting into geo-chemical recycling of heavy metal elements in these ecosystems. These heavy metals in sediments may be found immobilized, and at the same time can be involved in absorption, co-precipitation, and complex formations[2].Heavy metals are among the most common environmental pollutants, and their occurrence in waters confirms the presence of natural or anthropogenic sources. The existence of heavy metals in sediments of water bodies can affect on plant and animal life $[3,4]$.

District Badin is situated between $24^{\circ}-5^{\prime}$ to $25^{\circ}-25^{\prime}$ north latitude and $6821^{\prime}$ to $6920^{\prime}$ ' east longitude [5]. This district is bordered with Arabian Sea in South, the Rann of Kutch, and 
desert in South-Eastern side. Coastal belt of this district is very complex phenomenon and appears very vulnerable due to multi-directional anthropogenic and climatic conditions. This coastal belt gets contaminated due to mega drainage projects and sea tidal water.

Prior to the construction of Ghulam Mohammad Barragein 1955, coastal area of Badin was one of fertile parts of the Indus Delta. Annual floods had not only maintained ecology but also kept sea water away. But after the construction of barrage (flood protected embankment), the area was completely cut off, and coastal ecosystem started degrading due to sea tidal water $[5,6,7,8]$.New saline lakes appeared, on older deltic depressions' lands. Ecology of Badin further disturbed due to imbalance of polluted water supply, due to the introduction of two drainage systems in 1960s and 1980s respectively. The first one, Kotri barrage drain system comprises of Karo Gungro and Fuleli Guni Outfall drains, both drains, polluting coastal wetland like Sanhro, Mehro and Cholri shallow lakes. The second one is Left Bank Outfall
Drain (LBOD) which ends into Arabian Sea (Fig1).The project $\mathrm{LBOD}$ was aimed to mitigate water logging and salinity of an area of 1.27 million acres of three Districts of Sindh province in 1986 . This LBOD was initially aimed to drain out pumped saline water and agricultural runoff, but soon it carried municipal and industrial wastes along flood water towards the coastal areas of Badin. Badin coastal district became the final pathway of this contaminated water to Arabian Sea. LBOD has total discharge capacity of 4400 $\mathrm{m} 3 / \mathrm{s}$. It keeps flowing throughout the year. LBOD has other major components as Kadhan Pateji outfall drain (KPOD), Dhoro Puran Outfall Drain (DPOD), Tidal Link and Cholri weir (Fig1)[6,7]. The infrastructure of Tidal Link and Cholri weir found damaged completely after cyclone of 1999.This condition facilitated backflow of contaminated sea tidal water towards lakes and lagoons of coast (Fig1).The present study was focused to understand contamination of heavy metals of sediments in water bodies of coastal areas. The results were interpreted by using arc GIS application.

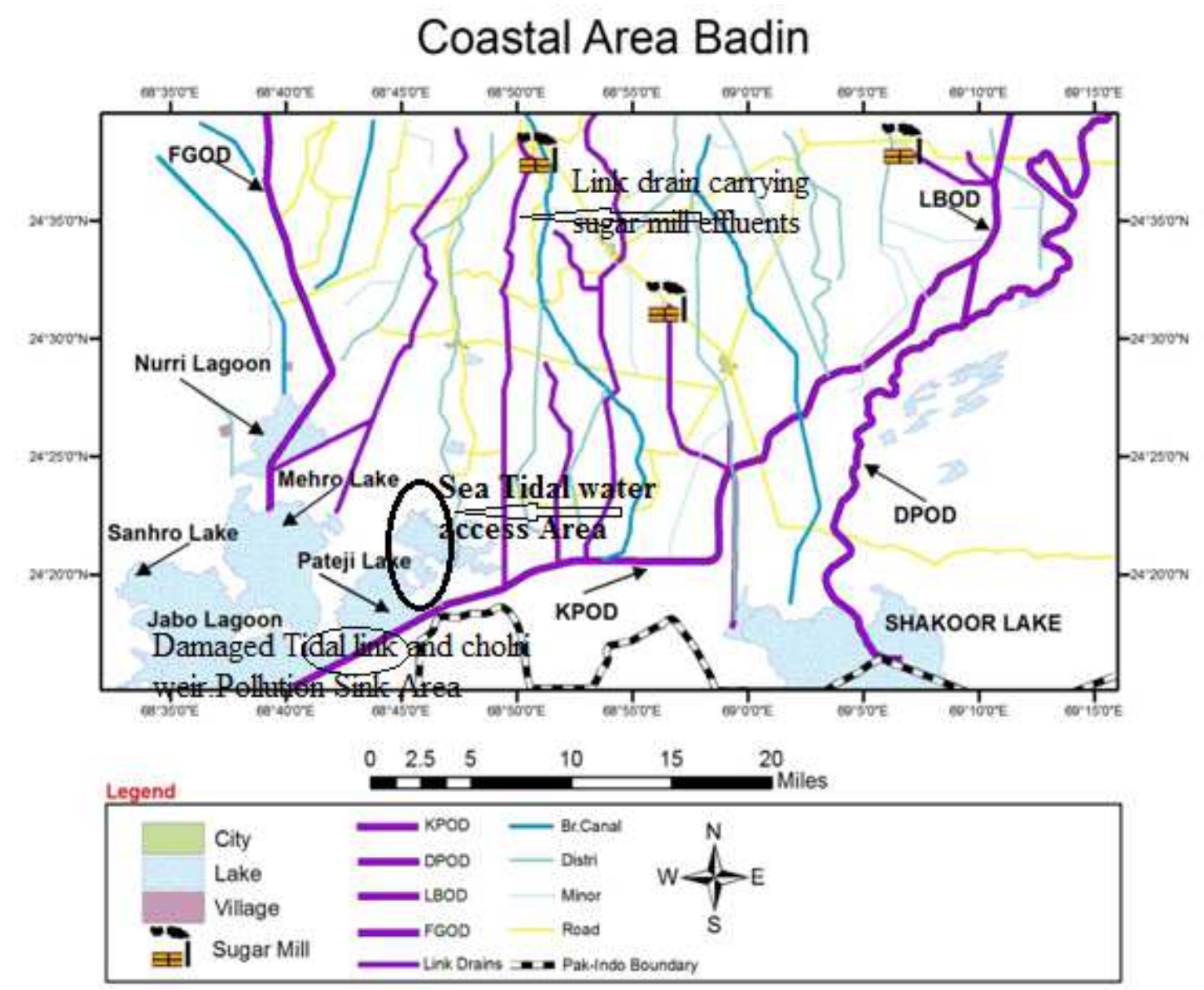

Fig.1. Base map ofstudied area.

\section{Experimental Methodology}

Sediment samples were collected from drains and shallow lakes and lagoons along with the coastal areas of Badin district (Fig 1).Samples were collected from 31 locations from 1 st -6 th march, and 1st to 6th of September of
2013.The sediment samples were collected from the selected stations using a grab sampler at depths of $0-20 \mathrm{~cm}$. The samples were kept tightly closed in polyethylene bags. All the sediment samples were stored in an insulated box containing ice and delivered to the laboratory. The samples were kept at $4^{\circ} \mathrm{C}$ until processing for analysis. Sediment 
samples were dried in an oven at $105 \mathrm{oC}$ overnight, sieved mechanically using a $0.5 \mathrm{~mm}$ sieve, homogenized and ground to $0.063 \mathrm{~mm}$ fine powder because metals are known to adhere to fine particles.

Sediment pollutants covering the total sorbed metals (cadmium, chromium, cobalt, copper, iron, lead, manganese, nickel, zinc) were determined by using strong acid extractants such as concentrated nitric acid (HNO3) and aqua Regia usingUS-EPA method \#3050 [9].10 ml of 1:1 HNO3 was added to $2 \mathrm{~g}$ of air dried sediments in a $150 \mathrm{ml}$ beaker.The samples were placed on hotplate, and covered with watch glass and heat (reflux) at $950 \mathrm{C}$ for 15 minutes. The digest was cooled, and $5 \mathrm{ml}$ of concentrated HNO3 added, reflux for an additional 30 minutes at $950 \mathrm{C}$. The last step was repeated and solution was reduced near to $5 \mathrm{ml}$, without boiling, beaker was partially covered. The sample was cooled again, and $2 \mathrm{ml}$ of deionized water and $3 \mathrm{ml}$ of $30 \%$ $\mathrm{H} 2 \mathrm{O} 2$ was added. With the beaker covered sample was heated gently to start the peroxide reaction. In case that effervescence became excessively vigorous the sample must be removed from the hot plate. $30 \% \mathrm{H} 2 \mathrm{O} 2$ was added, followed by gentle heating until the effervescence subsidized. Concentrated $\mathrm{HCl}$ and $10 \mathrm{ml}$ deionized water was added, and samples were refluxed for an additional $15 \mathrm{~min}$ without boiling. The samples were cooled, and filtered through Whatman No 42. The samples were diluted to $50 \mathrm{ml}$ with deinonized water for metal determination.The mercury was determined with coldvapour atomic absorption spectrometric method [9].

GIS was applied for collecting, storing, organizing, retrieving, transforming, and displaying data [10]. Arc GIS 9.2 was used for spatial analyses, and thematic mapsto map out the vector data[11]. GPS coordinates were usedto locate the sampling location.KMZ files were developed in Google earth and exported to Arc GIS for maps. The obtained results were used to make attribute table in arc GIS. By selecting symbology from properties, graduatedcircles and colors were selected to interpret the sediment results. The obtained results of parameters were divided into four classes, from lowest to highest ones.

\section{Result and Discussions}

Mercury has low solubility in aqueous solution; it is easily adsorbed on water-borne suspended particles. The waterborne $\mathrm{Hg}$ finally accumulates in the sediment, and the quantity of $\mathrm{Hg}$ contained in the sediment reflects the degree of pollution for the water body [12].The result of mercury concentration, as shown in Fig 2, is represented by graduated red circles, ranging in $0.0428-0.8333(\mathrm{mg} / \mathrm{kg})$. It was observed that mercury was in high concentration in the sediments of LBOD, DPOD, and KPOD, as compared to lakes and lagoons. Mercury was found reduced near damaged Cholri Weir areas of coastal waters.
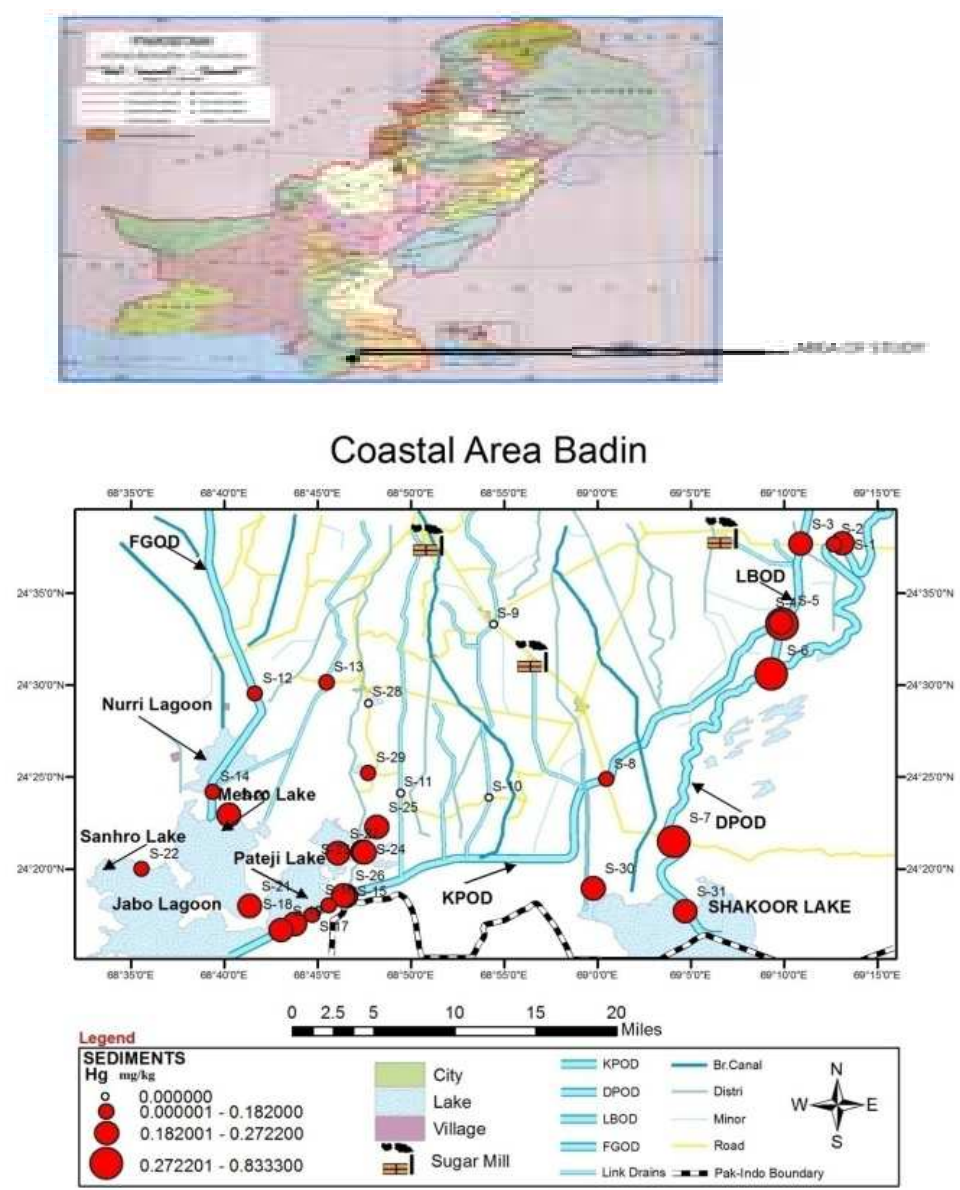

Fig. 2.Map of studied area showing mercury detection in sediment. 
The results of nickel as shown in Fig 3 were ranged in $0.0256-4.528 \mathrm{mg} / \mathrm{kg}$. It was observed that $\mathrm{Ni}$ was in high concentration in S-2, S-4, S-23, S-24, and S-25.Ni was found in reduced concentration near damaged Cholri Weir areas. The results were within guide line values (Nickel $20 \mathrm{mg} / \mathrm{kg}$ ) of EPA for heavy metal in sediments [13].

The results of $\mathrm{Zn}$ concentrations, as shown in Fig 4,ranged in $1.2-4.46 \mathrm{mg} / \mathrm{kg}$. The highest zinc range was found in S23(table 1). The $\mathrm{Zn}$ was observed reduced as moving towards tidal water. Conducting the study of sediment heavy metals in three lakes of China, by $\mathrm{Lu}$ and Cheng (2011), it was reported the $\mathrm{Zn}$ range of $58.67-93.22 \mathrm{mg} / \mathrm{kg}$ [14].The results were within guide line values (Zinc $90 \mathrm{mg} / \mathrm{kg}$ ) ofEPA for heavy metal in sediments [13].

The results of $\mathrm{Cu}$ concentrations as shown in Fig 5, with graduated red circles, ranged from $0.013-1.86 \mathrm{mg} / \mathrm{kg}$. The high concentration of $\mathrm{Cu}$ was observed at S-31 location. Chen et al. (2012), in a study conducted on distribution of copper in the sediments of Salt River Mouth, Taiwan were reported $\mathrm{Cu}$ range of $286-895 \mathrm{mg} / \mathrm{kg}$ [15].It was also reported, by Lu and Cheng (2011) while conducting study of sediments of heavy metals of three lakes of China, the $\mathrm{Cu}$ range $21.63-35.64 \mathrm{mg} / \mathrm{kg}$ in lakes of the area [14]. The results were within guide line values $(\mathrm{Cu} 25 \mathrm{mg} / \mathrm{kg})$ of EPA for heavy metal in sediments [13].
The result of iron content, as shown in Fig 6, was ranged $64.62-73.4 \mathrm{mg} / \mathrm{kg}$. It was observed that the iron concentration near coastal tidal water and damaged cholri weir was found reduced. The maximum range of Fe was observed in S-29.

The results of Mn concentration, as shown in Fig 7, ranged $3.28-9.134 \mathrm{mg} / \mathrm{kg}$. The maximum $\mathrm{Mn}$ was found in S-1, S-2, and S-4 locations (table 1). The results were within guide line values (Manganese $300 \mathrm{mg} / \mathrm{kg}$ ) of EPA for heavy metal in sediments [13].

The results of cobalt concentration, as shown in Fig 8, were found in the range of $0.062-0.144 \mathrm{mg} / \mathrm{kg}$. The cobalt was not found detected in 17 sampling location s.

The results of $\mathrm{Pb}$ concentration, as shown in fig 9, were within range of $0.024-0.435 \mathrm{mg} / \mathrm{kg}$ (table 2). The $\mathrm{Pb}$ was found maximum in the sample location $\mathrm{S}-1, \mathrm{~S}-2$. The results were within guide line values (Lead $40 \mathrm{mg} / \mathrm{kg}$ ) of EPA for heavy metal in sediments [13].

The results of $\mathrm{Cr}$ concentration as shown in Fig 10, was ranging from 0.562 to $1.983 \mathrm{mg} / \mathrm{kg}$. The $\mathrm{Cr}$ was found high in S-23, S-24, S-25, S-26, and S-27 locations. The results were within guide line values (chromium $25 \mathrm{mg} / \mathrm{kg}$ ) of EPA for heavy metal in sediments. The high concentration of chromium may be due to industrial effluents brought by main LBOD network from different districts. [13].

\section{Coastal Area Badin}

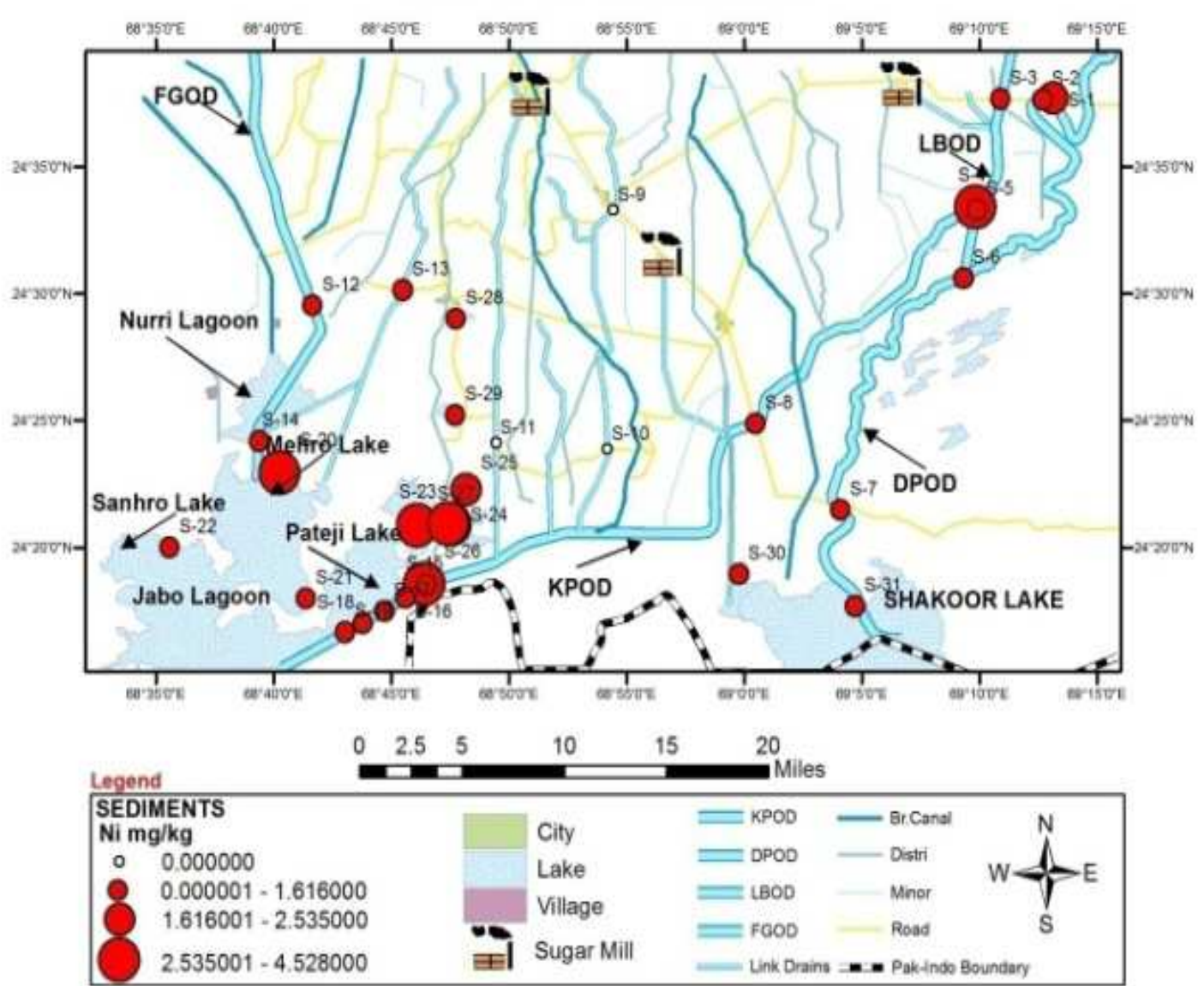

Fig. 3. Map of studied area showing detection of Ni in sediment. 


\section{Coastal Area Badin}

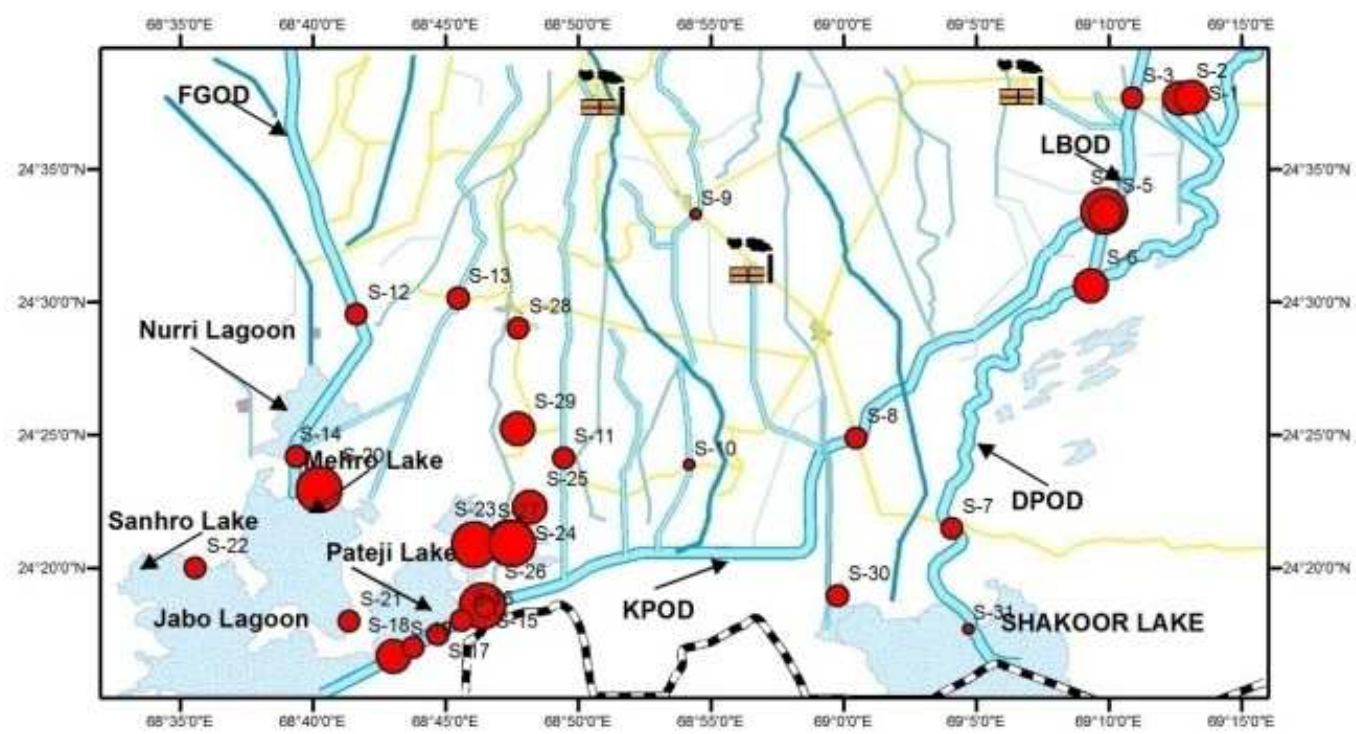

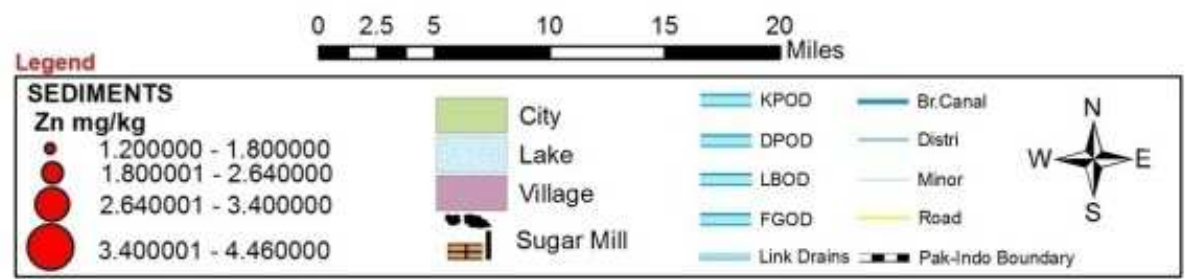

Fig. 4. Map of studied area showing Zinc detection in sediment.

\section{Coastal Area Badin}

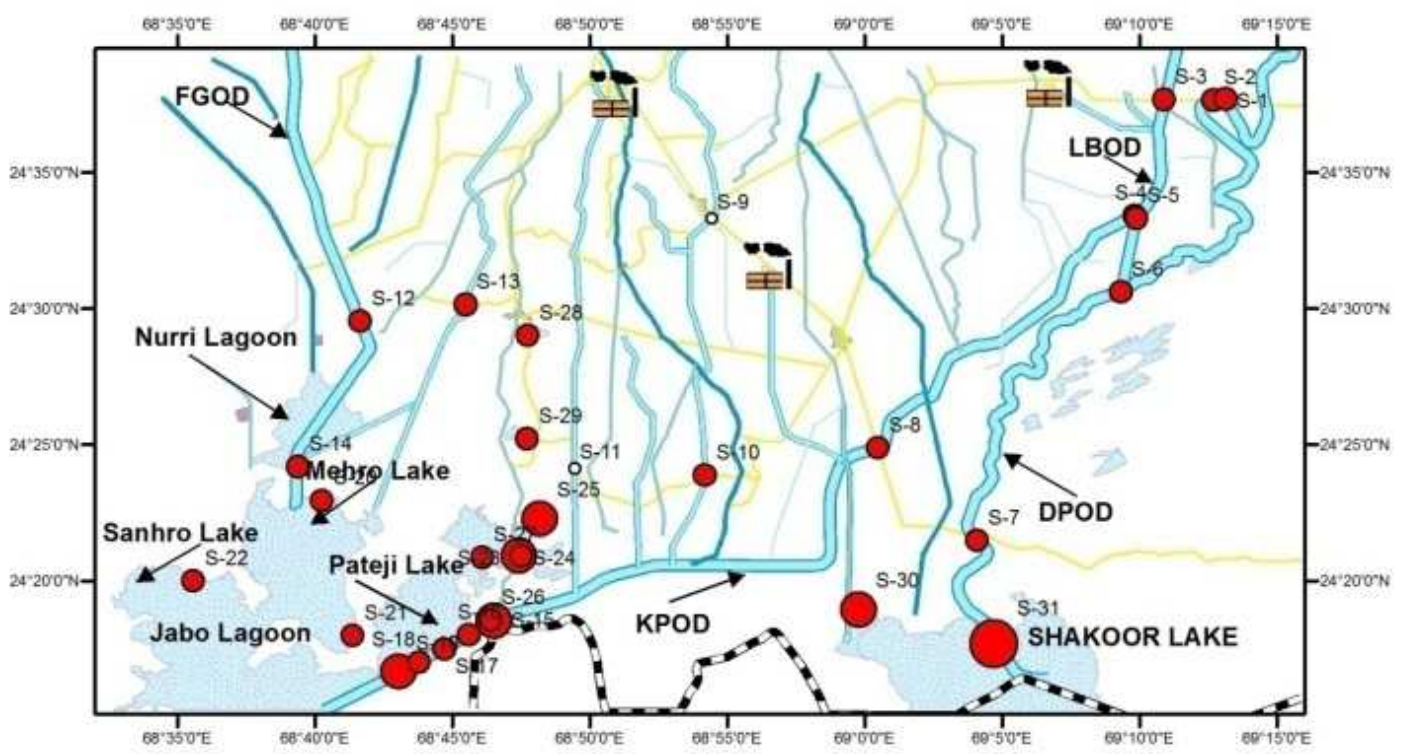

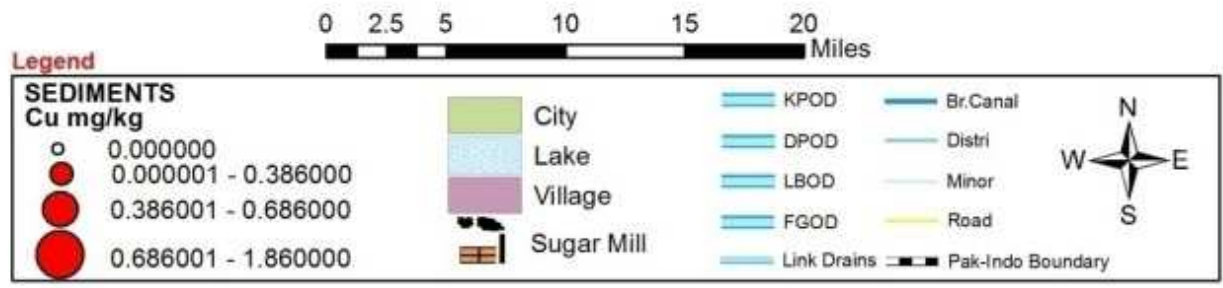

Fig. 5. Map of studied area showing Copper detection in sediment. 


\section{Coastal Area Badin}

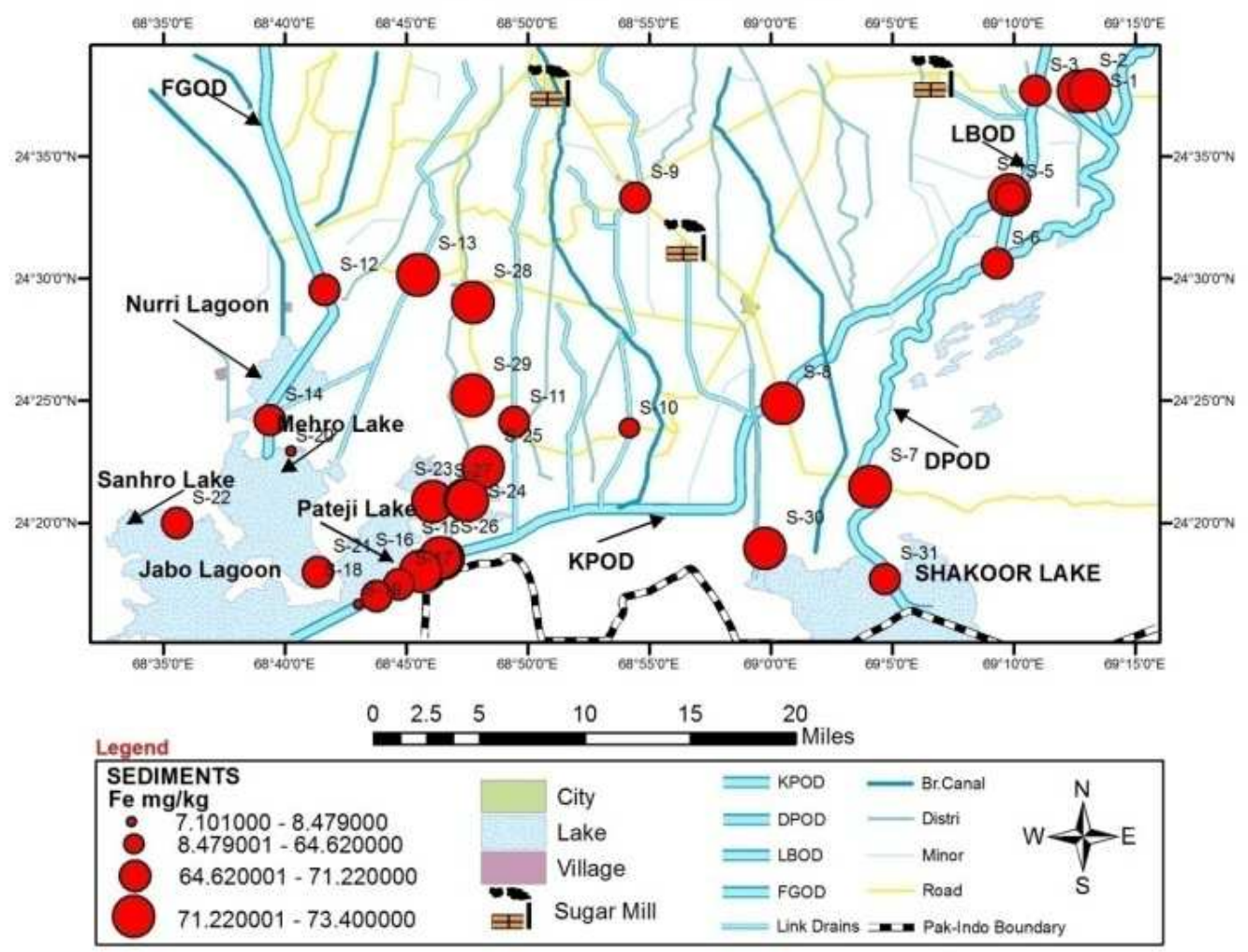

Fig. 6. Map s of studied area showing Fe detection in sediment.

\section{Coastal Area Badin}

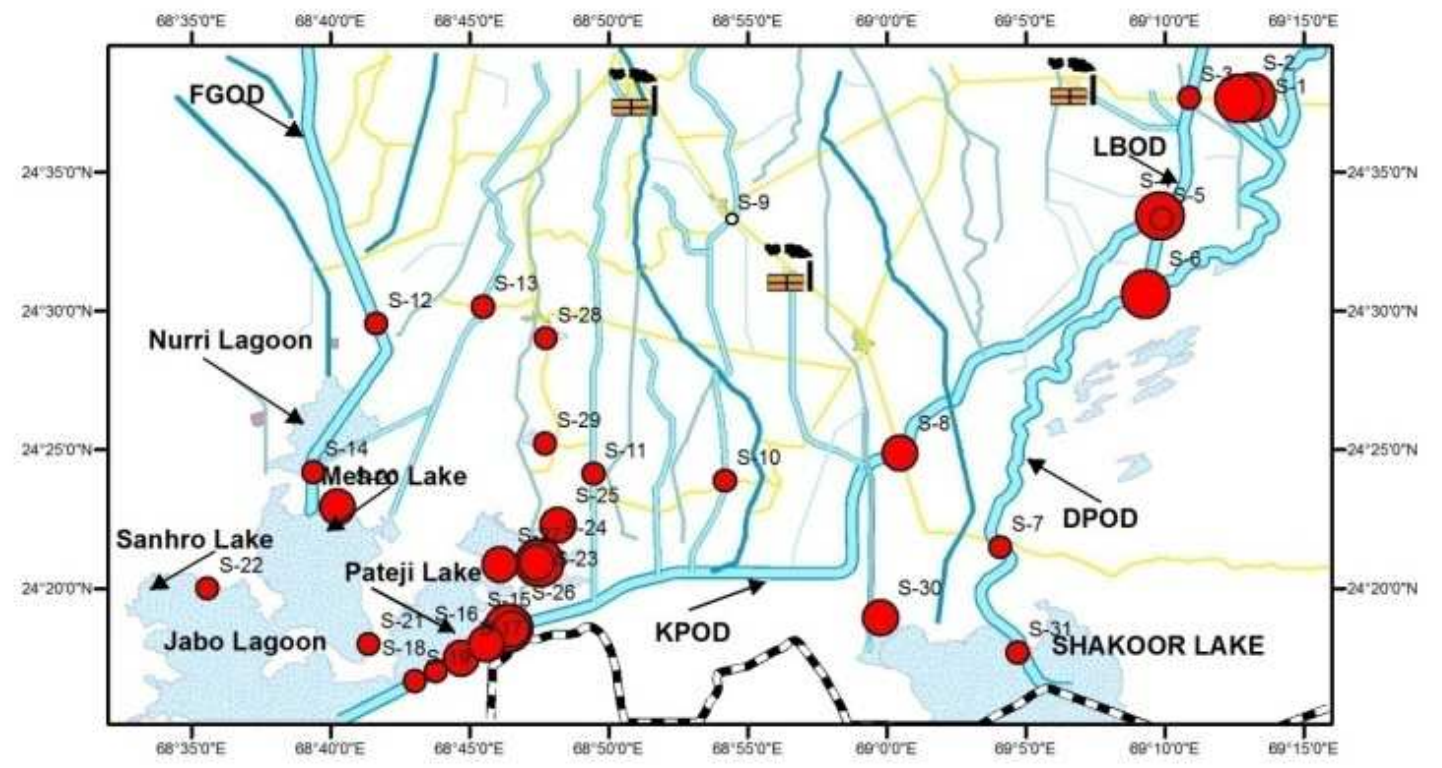

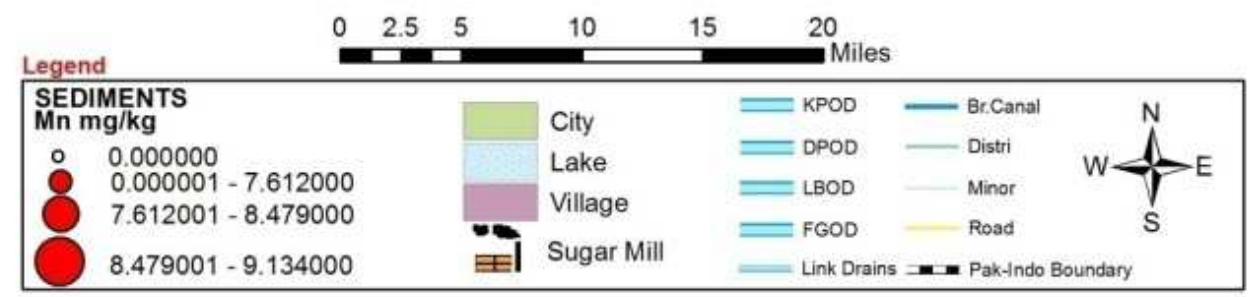

Fig. 7. Map of studied area showing Mn detection in sediment. 


\section{Coastal Area Badin}

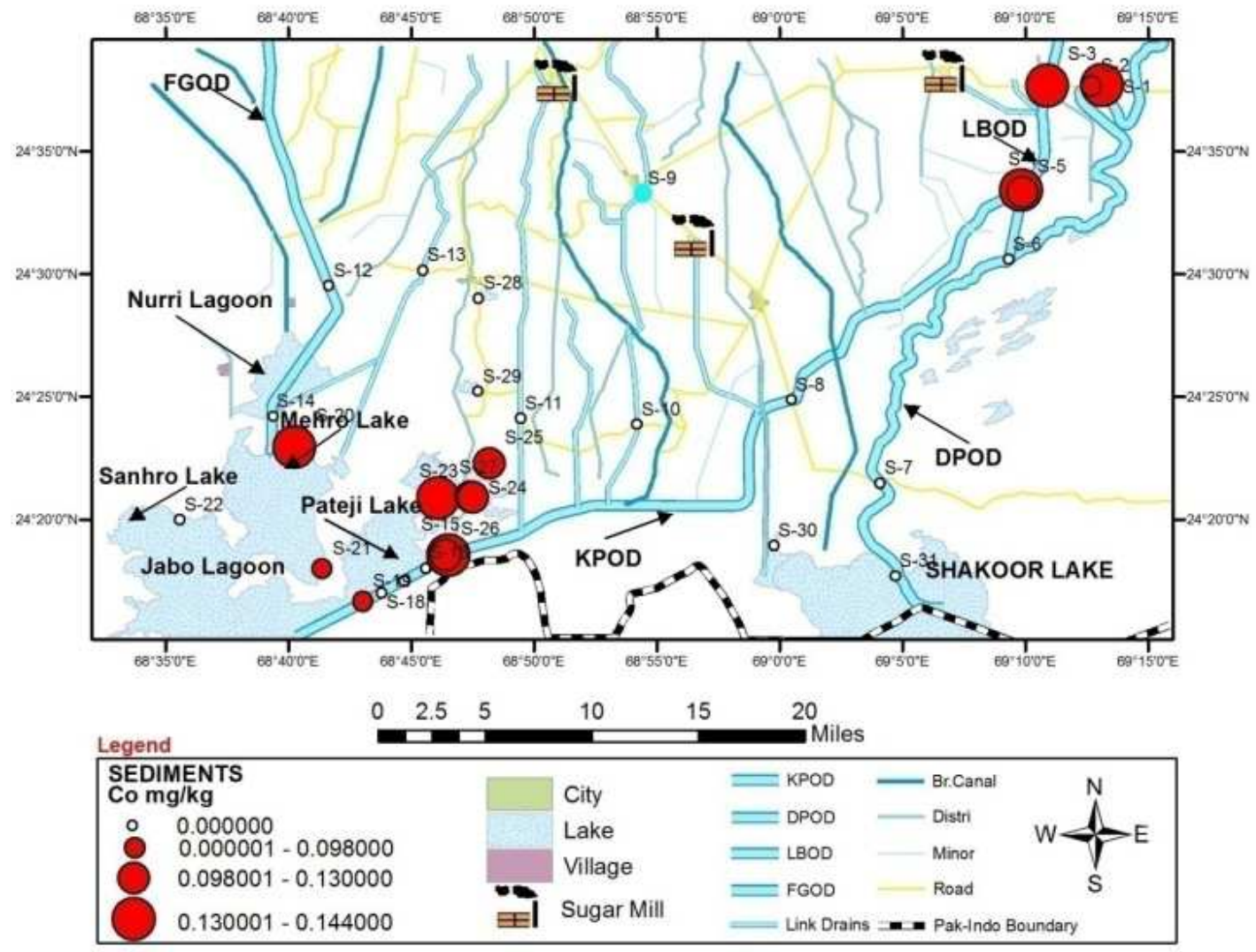

Fig. 8. Map of studied area showing Co detection in sediment.

\section{Coastal Area Badin}

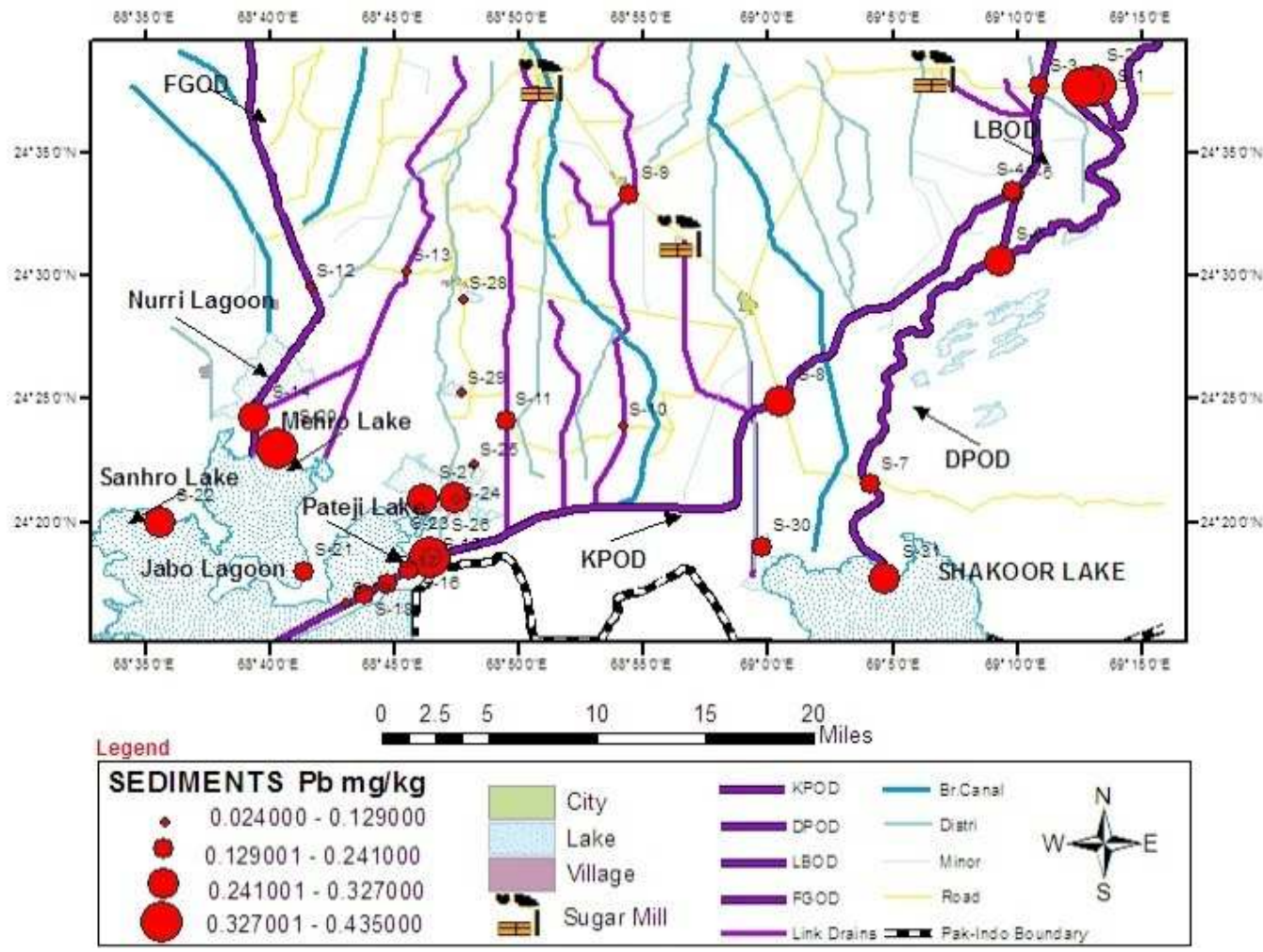

Fig. 9. Map of studied area showing Pb detection in sediment. 


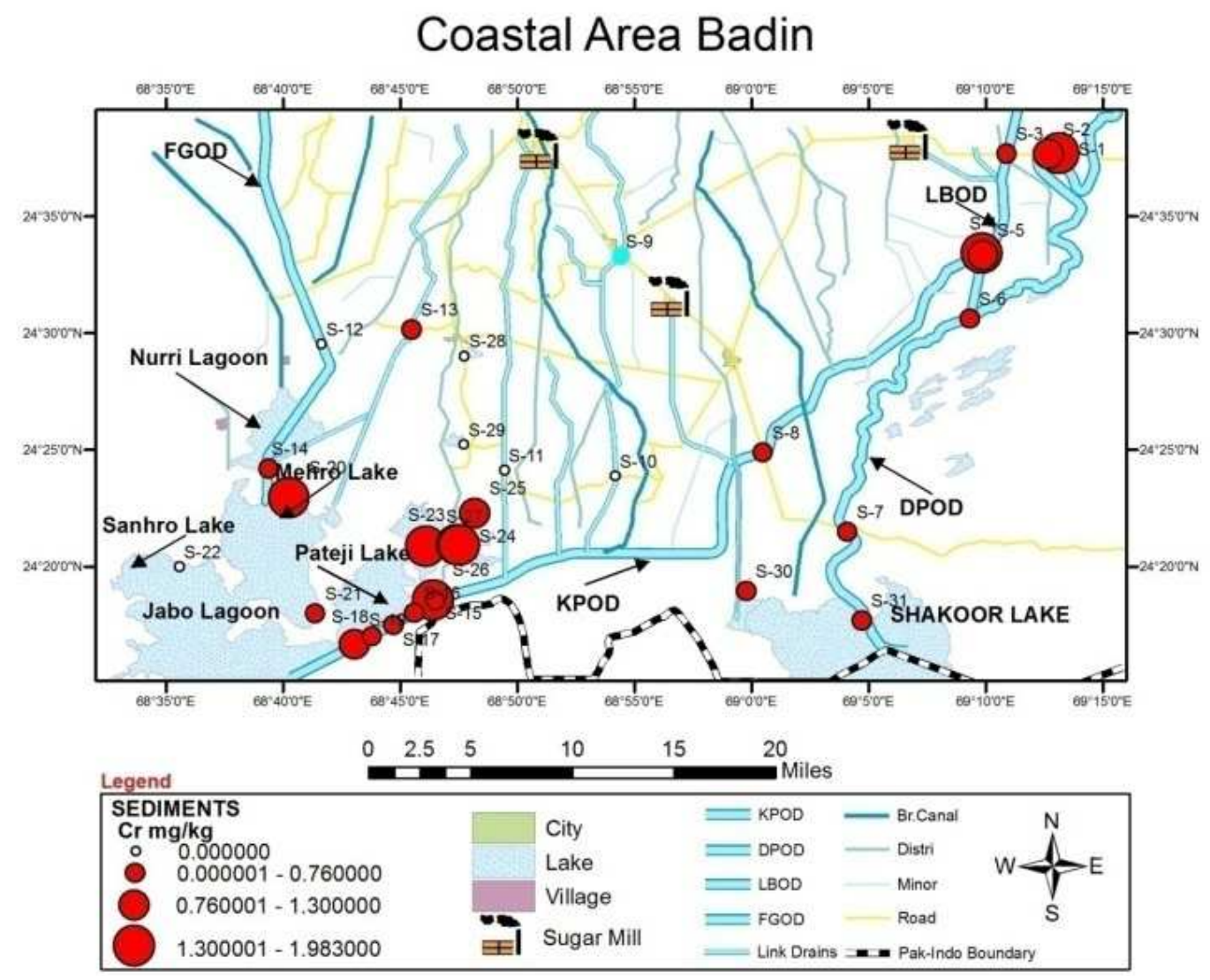

Fig. 10. Map of studied area showing Cr detection in sediment.

\section{Conclusion}

The coastal area of Badin is very vulnerable. The district is used as a pathway to dispose of saline pumped water, agriculture runoff along with the industrial effluents of three remote districts of province of Sindh. The waste water of main LBOD and damaged infrastructure of KPOD, tidal link and cholri weir has polluted the whole coastal area.

It was concluded that sediments of drains, lakes and lagoons of coastal areas have been more contaminated by anthropogenic activities. LBOD and other link drains carrying industrial and municipal wastes are major source of contamination of the areas.The mercury was in high concentration in the sediments of LBOD, DPOD, and KPOD, surface drains as compared to the areas of lakes and lagoons. This also confirms that $\mathrm{Hg}$ contamination source is main LBOD. High concentration of zinc was due to agriculture run off contributed by link drains near lakes. It was also observed that near Sea tidal water and damaged Cholri Weir area, heavy metal contents in sediments were in lowest concentration.

Table 1. heavy metal concentrations of sediments of coastal area Badin.

\begin{tabular}{|c|c|c|c|c|c|c|c|c|c|c|c|}
\hline \multicolumn{2}{|c|}{ No } & \multicolumn{10}{|c|}{ SamplingStations } \\
\hline 1 & $\begin{array}{l}\text { Sample } \\
\text { codes }\end{array}$ & S-1 & S-2 & S-3 & S-4 & S-5 & S-6 & S-7 & S-8 & S-9 & S-10 \\
\hline 2 & $\begin{array}{l}\text { Location } \\
\text { Names }\end{array}$ & $\begin{array}{l}\text { Dhoro } \\
\text { Puran(01) }\end{array}$ & $\begin{array}{l}\text { Dhoro } \\
\text { Puran (02) }\end{array}$ & $\begin{array}{l}\text { LBOD } \\
\text { at } \\
\text { Shadi } \\
\text { large }\end{array}$ & $\begin{array}{l}\text { KPOD at } \\
\text { bifurcation } \\
\text { point }\end{array}$ & $\begin{array}{l}\text { DPODat } \\
\text { bifurcation } \\
\text { point }\end{array}$ & $\begin{array}{l}\text { DPOD at } \\
\text { KathriJo } \\
\text { Band }\end{array}$ & $\begin{array}{l}\text { DPOD } \\
\text { at Ali } \\
\text { bander }\end{array}$ & $\begin{array}{l}\text { KPODat } \\
\text { kadhan }\end{array}$ & $\begin{array}{l}\text { Luari Sharif } \\
\text { Drain }\end{array}$ & $\begin{array}{l}\text { Luari } \\
\text { Drain } \\
\text { near } \\
\text { KPOD }\end{array}$ \\
\hline 3 & Latitude & 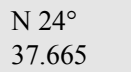 & $\begin{array}{l}\mathrm{N} \\
24^{\circ} 37.660^{\prime}\end{array}$ & $\begin{array}{l}\mathrm{N} 24^{\circ} \\
37.698\end{array}$ & $\begin{array}{l}\text { N } 24 \\
33.406\end{array}$ & $\begin{array}{l}\text { N } 24 \\
33.325\end{array}$ & $\mathrm{~N} 24^{\circ} 30.612$ & $\begin{array}{l}\mathrm{N} 24^{\circ} \\
21.490\end{array}$ & $\begin{array}{l}\mathrm{N} \\
24^{\circ} 24.888\end{array}$ & 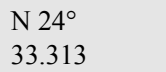 & $\begin{array}{l}\mathrm{N} 24^{\circ} \\
23.871\end{array}$ \\
\hline 4 & Longitude & $\begin{array}{l}\mathrm{E} 069^{\circ} \\
13.115\end{array}$ & $\begin{array}{l}\mathrm{E} 069^{\circ} \\
12.656\end{array}$ & $\begin{array}{l}\mathrm{E} 069^{\circ} \\
10.876\end{array}$ & $\begin{array}{l}\text { E069 } \\
09.822\end{array}$ & $\begin{array}{l}\text { E069 } \\
09.873\end{array}$ & E069 09.309 & $\begin{array}{l}\text { E069 } \\
04.090\end{array}$ & $\begin{array}{l}\mathrm{E}^{0} 69^{\circ} \\
00.473\end{array}$ & E068 54.429 & $\begin{array}{l}\mathrm{E} 068^{\circ} \\
54.191\end{array}$ \\
\hline \multicolumn{12}{|c|}{ Concentrations of heavy metals in sediments } \\
\hline 5 & $\mathrm{Hg}(\mathrm{mg} / \mathrm{kg})$ & 0.1988 & 0.1540 & 0.2144 & 0.1900 & 0.8333 & 0.6412 & 0.4684 & 0.1720 & N.D & N.D \\
\hline 6 & $\mathrm{Ni}(\mathrm{mg} / \mathrm{kg})$ & 2.535 & 1.242 & 1.246 & 3.643 & 1.616 & 1.246 & 0.9642 & 0.8560 & N.D & N.D \\
\hline 7 & $\mathrm{Cd}(\mathrm{mg} / \mathrm{kg})$ & N.D & N.D & N.D & N.D & N.D & N.D & N.D & N.D & N.D & N.D \\
\hline 8 & $\mathrm{Zn}(\mathrm{mg} / \mathrm{kg})$ & 3.26 & 3.36 & 2.62 & 4.07 & 2.91 & 2.80 & 2.46 & 2.14 & 1.20 & 1.80 \\
\hline
\end{tabular}




\begin{tabular}{llllllllllll}
\hline No & \multicolumn{1}{l}{ SamplingStations } \\
\hline 9 & $\mathrm{Cu}(\mathrm{mg} / \mathrm{L})$ & 0.118 & 0.180 & 0.315 & 0.375 & 0.013 & 0.046 & 0.026 & 0.248 & N.D & 0.032 \\
10 & $\mathrm{Fe}(\mathrm{mg} / \mathrm{kg})$ & 72.56 & 73.0 & 70.96 & 71.79 & 70.97 & 71.0 & 72.0 & 71.50 & 68.20 & 64.62 \\
11 & $\mathrm{Mn}$ & & & & & & & & & \\
$1 \mathrm{mg} / \mathrm{kg})$ & 9.063 & 9.0 & 7.438 & 9.099 & 7.420 & 8.60 & 7.36 & 8.24 & N.D & 3.28 \\
12 & $\mathrm{Co}(\mathrm{mg} / \mathrm{kg})$ & 0.144 & 0.098 & 0.136 & 0.134 & 0.130 & 0 & 0 & 0 & 0 & 0 \\
13 & $\mathrm{~Pb}(\mathrm{mg} / \mathrm{kg})$ & 0.435 & 0.389 & 0.204 & 0.210 & 0.223 & 0.327 & 0.201 & 0.321 & 0.189 & 0.102 \\
14 & $\mathrm{Cr}(\mathrm{mg} / \mathrm{kg})$ & 1.630 & 1.30 & 0.697 & 1.588 & 0.923 & 0.056 & 0.082 & 0.056 & N.D & N.D \\
\hline
\end{tabular}

Table 01 ${ }^{1}$. heavy metal concentrations of sediments of coastal area Badin.

\begin{tabular}{|c|c|c|c|c|c|c|c|c|c|c|c|}
\hline \multirow{2}{*}{$\begin{array}{l}\text { No } \\
1\end{array}$} & \multicolumn{11}{|c|}{ Sampling stations } \\
\hline & $\begin{array}{l}\text { Sample } \\
\text { codes }\end{array}$ & S-11 & S-12 & S-13 & S-14 & S-15 & S-16 & S-17 & S-18 & S-19 & S-20 \\
\hline 2 & $\begin{array}{l}\text { Location } \\
\text { Names }\end{array}$ & $\begin{array}{l}\text { Serani } \\
\text { Drain }\end{array}$ & $\begin{array}{l}\text { Ameer } \\
\text { Shah } \\
\text { drain }\end{array}$ & $\begin{array}{l}\text { Hamid } \\
\text { drain }\end{array}$ & $\begin{array}{l}\text { Nareri Zero } \\
\text { Drain }\end{array}$ & $\begin{array}{l}\text { KPOD } \\
\text { AtZero } \\
\text { point }\end{array}$ & $\begin{array}{l}\text { KPOD } \\
\text { Breach } 1\end{array}$ & $\begin{array}{l}\text { KPOD } \\
\text { Breach } 2\end{array}$ & $\begin{array}{l}\text { KPOD } \\
\text { Breach } 3\end{array}$ & $\begin{array}{l}\text { KPOD } \\
\text { Breach } 4\end{array}$ & Mehro lake \\
\hline 3 & Latitude & $\mathrm{N} 24^{\circ}$ & $\mathrm{N}$ & $\mathrm{N}$ & $\mathrm{N}$ & $\mathrm{N} 24^{\circ}$ & $\mathrm{N}$ & $\mathrm{N}$ & $\mathrm{N}$ & $\mathrm{N}$ & $\mathrm{N} 24^{\circ}$ \\
\hline 3 & Earituse & 24.122 & $24^{\circ} 29.519$ & $24^{\circ} 30.143$ & $24{ }^{\circ} 24.204$ & 18.528 & $24^{\circ} 17.990$ & $24^{\circ} 17.490$ & $24^{\circ} 17.000$ & $24^{\circ} 16.652$ & 22.953 \\
\hline 4 & Lonoitude & E068 & E068 & E068ํㄴ.4 & E068 & E068 & E068 ${ }^{\circ}$ & E06844.68 & E06843.79 & E0684․04 & E068 ${ }^{\circ} 40.2$ \\
\hline$r$ & Derig tur & 49.473 & 41.643 & 47 & 39.332 & 46.514 & 45.600 & 5 & 1 & 1 & 58 \\
\hline \multicolumn{12}{|c|}{ Concentrations of heavy metals in sediments } \\
\hline 5 & $\mathrm{Hg}(\mathrm{mg} / \mathrm{kg})$ & N.D & 0.0506 & 0.0428 & 0.1404 & 0.2100 & 0.1806 & 0.1250 & 0.2340 & 0.2177 & 0.1988 \\
\hline 6 & Ni (mg/kg) & N.D & 0.0684 & 0.0256 & 0.982 & 1.467 & 0.845 & 0.450 & 0.254 & 1.351 & 3.814 \\
\hline 7 & $\mathrm{Cd}(\mathrm{mg} / \mathrm{kg})$ & N.D & N.D & N.D & N.D & N.D & N.D & N.D & N.D & N.D & N.D \\
\hline 8 & $\mathrm{Zn}(\mathrm{mg} / \mathrm{kg})$ & 2.20 & 1.96 & 2.10 & 2.64 & 2.41 & 2.25 & 2.56 & 2.10 & 2.99 & 3.86 \\
\hline 9 & $\mathrm{Cu}(\mathrm{mg} / \mathrm{L})$ & N.D & 0.252 & 0.243 & 0.240 & 0.498 & 0.344 & 0.386 & 0.298 & 0.434 & 0.212 \\
\hline 10 & $\mathrm{Fe}(\mathrm{mg} / \mathrm{kg})$ & 69.3 & 71.2 & 72.6 & 70.5 & 72.19 & 71.40 & 71.22 & 70.50 & 70.45 & 71.73 \\
\hline 11 & $\mathrm{Mn}(\mathrm{mg} / \mathrm{kg})$ & 4.24 & 6.40 & 7.56 & 7.22 & 8.365 & 7.80 & 7.86 & 7.25 & 7.101 & 8.479 \\
\hline 12 & Co (mg/kg) & 0 & 0 & 0 & 0 & 0.136 & 0 & 0 & 0 & 0.084 & 0.138 \\
\hline 13 & $\mathrm{~Pb}(\mathrm{mg} / \mathrm{kg})$ & 0.156 & 0.129 & 0.105 & 0.280 & 0.170 & 0.190 & 0.182 & 0.156 & 0.112 & 0.382 \\
\hline 14 & $\mathrm{Cr}(\mathrm{mg} / \mathrm{kg})$ & N.D & N.D & 0.0842 & 0.562 & 0.684 & 0.720 & 0.426 & 0.760 & 0.920 & 1.543 \\
\hline
\end{tabular}

Table $01^{2}$. heavy metal concentrationsof sediments of coastal Badin.

\begin{tabular}{|c|c|c|c|c|c|c|c|c|c|c|c|c|}
\hline \multicolumn{2}{|c|}{ S.No } & \multicolumn{11}{|c|}{ SamplingStations } \\
\hline 1 & $\begin{array}{l}\text { Sample } \\
\text { codes }\end{array}$ & S-21 & S-22 & S-23 & S-24 & S-25 & S-26 & S-27 & S-28 & S-29 & S-30 & S-31 \\
\hline 2 & $\begin{array}{l}\text { Location } \\
\text { Names }\end{array}$ & $\begin{array}{l}\text { Jubho } \\
\text { lagoon }\end{array}$ & $\begin{array}{l}\text { Sanhro } \\
\text { lake }\end{array}$ & $\begin{array}{l}\text { Sandho } \\
\text { Dhandh }\end{array}$ & $\begin{array}{l}\text { Waryaro } \\
\text { Dhandh }\end{array}$ & $\begin{array}{l}\text { Chorhadi } \\
\text { Dhandh }\end{array}$ & $\begin{array}{l}\text { Pateji } \\
\text { lake. }\end{array}$ & $\begin{array}{l}\text { Bakradi } \\
\text { lake }\end{array}$ & $\begin{array}{l}\text { Khana } \\
\text { lake }\end{array}$ & $\begin{array}{l}\text { Bajorerro } \\
\text { lake }\end{array}$ & $\begin{array}{l}\text { Kanderri } \\
\text { lake }\end{array}$ & $\begin{array}{l}\text { Shahkoor } \\
\text { lake }\end{array}$ \\
\hline 3 & Latitude & $\begin{array}{l}\mathrm{N} 24^{\circ} \\
17.992\end{array}$ & $\begin{array}{l}\mathrm{N} 24^{\circ} \\
19.989\end{array}$ & $\begin{array}{l}\mathrm{N} 24^{\circ} \\
20.926\end{array}$ & $\begin{array}{l}\mathrm{N} 24^{\circ} \\
20.904\end{array}$ & $\begin{array}{l}\mathrm{N} 24^{\circ} \\
22.281\end{array}$ & $\begin{array}{l}\mathrm{N} 24^{\circ} 18 \\
.543\end{array}$ & $\begin{array}{l}\mathrm{N} 24^{\circ} 20.8 \\
54\end{array}$ & $\begin{array}{l}\text { N24 } 29 . \\
025\end{array}$ & $\begin{array}{l}\mathrm{N} 24^{\circ} 25.21 \\
6\end{array}$ & $\mathrm{~N} 24^{\circ} 18.944$ & $\begin{array}{l}\mathrm{N} 24^{\circ} 17.7 \\
71\end{array}$ \\
\hline 4 & Longitude & $\begin{array}{l}\text { E068 }{ }^{\circ} 413 \\
82\end{array}$ & $\begin{array}{l}\text { E068 } \\
35.582\end{array}$ & $\begin{array}{l}\text { E068 } 47.4 \\
13\end{array}$ & $\begin{array}{l}\mathrm{E} 068^{\circ} 4 \\
7.510\end{array}$ & $\begin{array}{l}\text { E068 } \\
48.176\end{array}$ & $\begin{array}{l}\mathrm{E} 068^{\circ} 4 \\
6536\end{array}$ & $\begin{array}{l}\text { E0684․ } \\
071\end{array}$ & $\begin{array}{l}\text { E068 } 47 \\
.711\end{array}$ & $\begin{array}{l}\mathrm{E} 068^{\circ} 47.7 \\
25\end{array}$ & $\begin{array}{l}\text { E068 } 59.77 \\
1\end{array}$ & $\begin{array}{l}\mathrm{E} 069^{\circ} .04 . \\
756\end{array}$ \\
\hline \multicolumn{13}{|c|}{ Concentrations of heavy metals in sediments } \\
\hline 5 & $\mathrm{Hg}(\mathrm{mg} / \mathrm{kg})$ & 0.1944 & 0.1820 & 0.2333 & 0.2133 & 0.2722 & 0.1922 & 0.2077 & N.D & 0.1426 & 0.2046 & 0.1860 \\
\hline 6 & $\mathrm{Ni}(\mathrm{mg} / \mathrm{kg})$ & 0.216 & 0.1528 & 3.619 & 4.453 & 2.177 & 4.291 & 4.528 & 0.5684 & 0.2460 & 1.026 & 1.246 \\
\hline 7 & $\mathrm{Cd}(\mathrm{mg} / \mathrm{kg})$ & N.D & N.D & N.D & N.D & N.D & N.D & N.D & N.D & N.D & N.D & N.D \\
\hline 8 & $\mathrm{Zn}(\mathrm{mg} / \mathrm{kg})$ & 2.33 & 2.60 & 4.46 & 4.24 & 3.06 & 4.22 & 4.31 & 2.33 & 3.40 & 2.56 & 1.26 \\
\hline 9 & $\mathrm{Cu}(\mathrm{mg} / \mathrm{L})$ & 0.365 & 0.150 & 0.593 & 0.328 & 0.415 & 0.199 & 0.298 & 0.180 & 0.124 & 0.686 & 1.860 \\
\hline 10 & $\mathrm{Fe}(\mathrm{mg} / \mathrm{kg})$ & 70.95 & 70.2 & 71.88 & 71.85 & 72.25 & 71.88 & 71.95 & 72.3 & 73.4 & 71.6 & 70.5 \\
\hline 11 & $\mathrm{Mn}(\mathrm{mg} / \mathrm{kg})$ & 7.193 & 7.440 & 8.243 & 8.755 & 8.018 & 9.134 & 8.115 & 7.612 & 7.324 & 7.820 & 7.210 \\
\hline 12 & $\mathrm{Co}(\mathrm{mg} / \mathrm{kg})$ & 0.062 & 0 & 0.129 & 0.121 & 0.125 & 0.124 & 0.140 & 0 & 0 & 0 & 0 \\
\hline 13 & $\mathrm{~Pb}(\mathrm{mg} / \mathrm{kg})$ & 0.241 & 0.280 & 0.312 & 0.062 & 0.034 & 0.432 & 0.302 & 0.024 & 0.034 & 0.202 & 0.310 \\
\hline 14 & $\mathrm{Cr}(\mathrm{mg} / \mathrm{kg})$ & 0.556 & N.D & 1.854 & 1.844 & 1.145 & 1.983 & 1.974 & N.D & N.D & 0.246 & 0.236 \\
\hline
\end{tabular}


Table 02. (average, standard deviation, min, max)heavy metyal concentrations of sediments of badin coastal area.

\begin{tabular}{|c|c|c|c|c|c|c|c|c|c|c|}
\hline Heavy metal & Hg & $\mathbf{N i}$ & Cd & Zn & $\mathrm{Cu}$ & $\mathrm{Fe}$ & Mn & Co & $\mathbf{P b}$ & $\mathrm{Cr}$ \\
\hline AVERAGE & 0.2032 & 1.455 & BDL & 2.789 & 0.3050 & 71.175 & 7.375 & 0.0548 & 0.216 & 0.7054 \\
\hline ST DEV & 0.173 & 1.449 & BDL & 0.865 & 0.3355 & 1.610 & 1.848 & 0.0634 & 0.114 & 0.6949 \\
\hline MIN & 0.0428 & 0.0256 & BDL & 1.2 & 0.013 & 64.62 & 3.28 & 0.062 & 0.024 & 0.562 \\
\hline MAX & 0.8333 & 4.528 & BDL & 4.46 & 1.86 & 73.4 & 9.134 & 0.144 & 0.435 & 1.983 \\
\hline
\end{tabular}

\section{References}

[1] US EPA 2007.Sediment Toxicity Identification Evaluation (TIE) Phases I, II, and III. Guidance Document US EPA Washington, DC20460.

[2] Sekabira, K.Oryem Origa,H.Basamba, T. A. Mutumba,G. Kakudidi,E.2010. Assessment of heavy metal pollution in the urban stream sediments and its tributaries.Int. J. Environ. Sci. Tech., 7 (3), 435-446.

[3] Aprile, F.M. and Bouvy, M.2008. Distribution and enrichment of heavy metals in sediments at the Tapacura river basin north eastern Brazil. J. Aquat. Sci. Technol., 12(1), 1-8.

[4] Iwuoha, G.N. Osuji, L.C. Horsfall, M. Jnr. 2012.Index Model Analysis Approach to Heavy Metal Pollution Assessment in Sediments of Nworie and Otamiri Rivers in Imo State of Nigeria. Research Journal of Chemical Sciences Vol. 2(8), 1-8.

[5] IUCN 2006. District Vision-Badin. A Framework for Sustainable Development.

[6] SIDA 2013. Sindh Water Sector Improvement ProjectI.Regional master plan of Indus delta and coastal zone.Revival of Natural Dhoras Sindh Water. Sector Improvement Plan for Left Bank of Indus, Delta and Coastal Zone.

[7] LBOD 2005.Review of the Performance of the Left Bank Out fall Drain Stage 1 (KPOD, DPOD, Tidal Link and Cholri Weir) Report of the World Bank International Panel of Experts South Asia Region. Agriculture and Rural Development.
[8] EIA 2012. Environmental Impact Assessment for Exploration Activities in Badin Concession - Protected Area Final report.

[9] Gupta, P.K. 2011. Methods in Environmental Analysis Water, Soil and Air. $2^{\text {nd }}$ Edition Agribios India.

[10] Burrough, P.A. 1986. Principles of Geographic Information System for land Resources Assessment Monograph on Soils and Resources, Survey No.2. Clarendon Press, Oxford, England.

[11] Facchinelli A. , Sacchi E. , Mallen L.,2001. Multivariate statistical and GIS-based approach to identify heavy metal sources in soils. J. Environ. Pollut.114, 313-324.

[12] Chen C.W., Chen C.F., Dong C.D., 2012. Distribution and Accumulation of Mercury in Sediments of Kaohsiung River Mouth, Taiwan APCBEE Procedia 1153 - 158.

[13] OgbeibuA.E., OmoigberaleM.O., EzenwaI.M., EzizaJ.O., IgweJ.O.,2014.Using Pollution Load Index and Geoaccumulation Index for the Assessment of Heavy Metal Pollution and Sediment Quality of the Benin River, Nigeria. Natural Environment, 2(1), 1-9.

[14] LuC.X., ChengJ., 2011.Speciation of Heavy Metals in the Sediments from Different Eutrophic Lakes of China. Procedia Engineering, 18, 318-323.

[15] ChenC.W. Chen C.F., Dong C.D. 2012.Copper Contamination in the Sediments of Salt River Mouth, Taiwan Energy Procedia, 16,901-906. 